\title{
THE PORTRAIT OF DR. WILLIAM SALTER.
}

One of the most pleasing events that has ever transpired: in the State Historical Department, was the public presentation to the State, November 24, 1902, of a fine oil portrait. of this illustrious clergyman and author, of the city of Burlington. Few other men of his sacred calling, in any State of the Union, have ever come to occupy so high a place in. the esteem and affection of the people throughout a wide acquaintance. It is most appropriate that his portrait should. occupy a place of bonor in the State Historical Art Gallery. The movement through which this portrait was secured was: due to the efforts of Hon. Messrs. Frank Springer, of Las Vegas, N. M., and Philip M. Crapo, of Burlington. The other donors were Mr. and Mrs. C. E. Perkins, Mr. and Mrs. C. P. Squires, Mr. and Mrs. William Carson, Mr. and Mrs. Thomas Hedge, Mr. and Mrs. H. S. Rand, Mr. and Mrs. C. H. Higbee, Mr. and Mrs. J. W. Blythe, and Mr. and Mrs. Lasell.

The following gentlemen from the city of Burlington were in attendance at the presentation: Rev. Robert L. Marsh, Rev. Ludwig Holmes, J. R. Nairn, J. F. Segner, F. A. Mil. lard, Robert Donahue, Luke Palmer, S. P. Gilbert, GeorgeB. Salter, and Philip M. Crapo. Arthur Springer, of Columbus Junction, and Hon. Frank Springer, of Las Vegas, N. M., were also in attendance.

Rev. Dr. A. L. Frisbie, of Des Moines, kindly consented. to preside. In taking the chair he paid a brief but most appreciative tribute to the life-work of Rev. Dr. Salter, his. long time co-laborer in the Congregational Church of Iowa, and introduced Hon. Frank Springer, who spoke as follows:

It is a kindly maxim, born of the generous instincts of human nature, that we shall say nothing but good of those who are dead. It lends a melancholy pleasure to our memorial occasions, and often imparts to our thoughts at such times a kindness and charity which we do not always feel toward our fellow men, amid the asperities and harsh contentions of every day life. When, however, there is found one living, and who has lived long. 
among us, of whom, by the common consent of all who have ever known him, nothing but good can be said, the impulse to do him honor may well touch even a tenderer chord, so that for the moment we may be possessed by the finer emotions of our natures, to which it would be well indeed if we yielded ourselves more often. And it is not strange that at such a time we should desire by committing to the State on enduring canvas a just delineation of his features to signify our appreciation of a character like this without waiting for the signal of the grim messenger to remind us that the time for doing justice is at hand.

It does not require the softening touch of time nor the chastening hand of death to round off the career of William Salter, so that we may justly characterize or fittingly commemorate it. His sixty years of citizenship in the State, marshaling for us their memories of a blameless life, come forward as witnesses, and we point to them as the reasons why we are here today.

I do not deem this a time for extended eulogy or biography of this good man. Coming to Iowa in 1843 and settling shortly afterward in Burlington as a minister of the gospel, he has remained in the pulpit which he adorned for over fifty years. And now, in the evening of a grand and ueeful life, when the shadows are beginning to lengthen, and while he looks with calmness upon the low descending sun, he is engaged in finishing, in the vigor of an intellect which his eighty years have scarcely dimmed, and with all the enthusiasm of earlier days, a history of the State he has loved and honored so long.

His life, spent in the pursuit and practice of his sacred calling, has necessarily been quiet and uneventful. And yet it spans the period during which this State was transformed from a primeval wilderness into the imperial commonwealth we behold it now. It represents the history of Iowa. He was a part of it; he helped to make it, and he is better qualified to relate it for the benefit of those coming after than any man now living.

We are apt to forget, in the rush and stress of a busy life, that we are making history as we go along. And those who have borne a part in the building of this marvelous commonwealth of yours can render no greater service to the young generation to which they have transmitted it than to leave their own memorials of the times through which they have lived. By no other means can the youth of this day gain so true a conception of the mighty work of the fathers, or of the transcendent grandeur of their own State.

Great not merely in her wondrous resources and amazing progress, in the matchless fertility of her soil, in her schools and her charities, in the patriotism and heroic records of her citizens, but because, with her rural population, full of intelligence, thought and calm reflection, and with her freedom from the curse of large cities, she rcpresents more nearly than any other community on this continent, the genius of republican institutions. Small wonder that she holds today such weighty influence in the councils and policies of the nation, or that presidents, when they want to. 
feel the pulse of pablic sentiment, should make pilgrimages to her borders and get in speaking distance of her people.

These reflections may seem not quite in keeping with the spirit of this occasion, but they come unbidden in the presence of these reminders of the men who made this splendid community. And, besides, much may be excused to one whom the chances of life, in early manhood, led into other fields, but who, after having borne an humble part in the building up of another community, and having also seen somewhat of the best that man and nature have done elsewhere, both at home and abroad, still counts as among the most valued of all his possessions his birthright in this great State.

As for enlogy, it would be difficult to portray in words the deep and abiding affection which exists for this venerable man in the hearts of those to whom and to whose people he has ministered, in their joys and in their sorrows, for more than half a century. I speak not merely of those who were members of his own congregation. His influence and his good works were never confined to such narrow limits. He belonged to the people of Iowa. Wherever there were wounded hearts to heal, or darkened souls to be cheered by the light of hope; wherever the poor in spirit were to be comforted; wherever the friendless needed recognition or encouragementthere he was found. What their creed was he never stopped to inquire.

In the times that tried our souls, when the sons of Iowa were offering their lives that the nation might live, he went into the field, preaching the gospel of patriotism, fortitude and good cheer to our heroes at the front. In war and in peace, to the camp and to the hearthstone, he has brought to grateful thousands of Iowa's best and noblest sons and daughters the consolations not only of religion but of a charity not bounded by any church or creed, but broad as the precepts of his Divine Master. There is scarcely a family in southeastern Towa, among the pioneers who builded the State, and their descendants to whom, at some time and in some way, his words have not been a comfort and his presence a benediction.

Foremost in all good works; a friend of liberal education; a promoter of learning in its broadest sense; an outspoken champion of right principles wherever right and wrong joined issue-his example has been a blessing to his fellow men and his life an honor to the State.

As a slight evidence of the affection and honor in which they hold him, the citizens of Burlington have caused to be executed a faithful portrait of $\mathrm{Dr}$. Salter as he appears today. No eulogy that I could pronounce would be half so eloquent or significant as this testimonial, coming as it does from his fellow citizens, who claim him as peculiarly their own. The donors of this picture have delegated to me the pleasing office of presenting it to the State. I esteem it a high privilege and an honor to be thus associated with them, and in their company to feel myself, for the moment, a citizen of Iowa again.

And therefore, sir (to Gov. A. B. Cummins), on behalf of the people of Burlington, and of the thousands of others who will be gratified by the 
event, I tender this portrait for your acceptance as the property of the State, hoping that it may find a worthy place in this pantheon of hor great men.

The portrait was draped with the beautiful Henderson flag which was slowly lowered by Hon. Philip M. Crapo at the conclusion of Mr. Springer's appropriate address. In a few well chosen remarks the gift was accepted by Gov. A. B. Cummins, who paid high tribute to the venerable clergyman, who is so widely known even far beyond the boundaries of Iowa. He quoted Dr. Frank W. Gunsaulus to the effect that the people of this State combined more of the qualities of good citizenship than those of any other State in the Union. "This," said the Governor, "was due to the Rev. Dr. Salter and his associates in the pioneer period of the State. . . . I believe the men and women of this generation ought to be forever grateful for the instruction, the spirit that has come down to us from former times. It is fitting that we should express in the manner we are doing today the gratitude that must fill every loyal heart."

At the conclusion of the Governor's remarks letters of regret were read from U. S. Senator W. B. Allison, the reverend and venerable Ephraim Adams, of Waterloo, Hon. Eugene Secor, of Forest City, Hon. Thomas Hedge, of Burlington, Maj. Hoyt Sherman, of Des Moines, Judge W. I. $\mathrm{Babb}$, of Mt. Pleasant, and other distinguished persons.

\section{GENERALS DODGE AND WILLIAMSON.}

None of the surviving soldiers of the civil war have ever surpassed Gen. G. M. Dodge in sincere sympathy for his comrades who have passed on before. Not long ago we saw him organize and carry out an effort to honor the memory of Col. W. H. Kinsman, and just now he has paid a splendid tribute to the late Gen. James A. Williamson. This last is in the form of a memoir of that distinguished Iowa soldier, which filled many columns in The Des Moines Daily Regis- 
Copyright of Annals of Iowa is the property of State of Iowa, by \& through the State Historical Society of Iowa and its content may not be copied or emailed to multiple sites or posted to a listserv without the copyright holder's express written permission. However, users may print, download, or email articles for individual use. 